\title{
Fandom versus citizenship: the "weirdisation" of politics
}

\section{Delia Chiaro}

Università di Bologna, Italy

delia.chiaro@unibo.it

\section{Nikita Lobanov}

Università di Bologna, Italy nikita.lobanov2@unibo.it

\begin{abstract}
This paper examines occurrences of humour in Twitter-fed celebrity-follower communities. Using a small, one-month sample of the Twitter feeds of 12 British celebrities, we examined political and humorous content of celebrity tweets and the first five responses from their followers. From this preliminary study, we found that the notion of "weirdisation" strongly emerges, together with the new conceptual tool of "shards of humour".
\end{abstract}

Keywords: fandoms; Twitter; celebrities; networks; tribalisation

\section{Introduction}

In modern democracies, humour has traditionally been prominent in a variety of communicative interactions and, most importantly, has marked groups of people in terms of identity and allegiance between the public and the political sphere. Recently, while levels of public participation in formal democratic processes have fluctuated, fallen, or remained low, forms of public interaction on political matters appear to have surged in volume on social media. Simultaneously, mass media celebrities have largely displaced politicians as primary charismatic authorities. This merging of socio-political developments prompts the question: how do politics and humour interact in these new mediated forms of communicative communities involving celebrity authorities? In this paper, we pursue this inquiry by focusing on such new groups of people, namely, the virtual communities of fans and followers revolving around given entertainment and sports celebrities. Drawing on the wider scholarly literature, we identify several hypotheses that might be applied to such Twitter-fed celebrity-follower communities. We then test these hypotheses using a one-month sampling of the Twitter feeds of 12 leading British celebrities together with an analysis of the first five responses from followers focusing on their political and humorous content. Since such work is still in its relative 
infancy and the phenomenon in question itself rapidly changing, we register several methodological challenges and develop two new conceptual tools: weirdisation and shards of humour in determining and documenting our preliminary findings.

\section{Humour, fandoms, and social media}

As suggested by Shifman \& Lemish (2010: 1-2), a vast quantity of internet content is humorous in intent. In fact, as one of the many functions of humour is social and often used as a means of gelling with others (Martin 2007: 5), much interaction on social media platforms such as Facebook and Twitter is designed to amuse and entertain. Twitter allows users to assemble around hashtags, a phenomenon that has resulted in the emergence of a variety of online communities that, through the way in which many hashtags and ensuing comments are couched, appears to be flagged by cultural units of meaning, i.e., memes, and predominantly humorous discourse (Shifman 2014: 78-81). According to Hwang (2010: 122), the consequences of this phenomenon are that "some of the most dramatic mobilisations on the Web have accumulated around humorous pictures of cats or long-lost '80s pop stars." Hwang may appear to be overstating the case, but undeniably, almost any newsworthy incident is usually followed by bouts of irony on social media, often in the form of image macros or so-called internet memes (Shifman 2014). Since the most egregious aspects of politics are newsworthy, political ideas and opinions become embroiled in online interaction and internet humour is likely to contaminate political content too. As Shifman (2007: 190-191) argues, the internet is a major player in the production and distribution of humour and, given that comedic texts bring dominant ideologies and cultural codes into play, as maintained by Billig (2005), it is not surprising that highly charged political issues appear in a variety of humorous forms online. Significantly, as pointed out by Jackson \& Thorsen (2015: 8), the 2015 general elections in Great Britain were notably "citizen-led campaigns to counter press power through parody."

At this point fandoms enter the equation. People who make up a fandom will share a common concern and spend substantial time and energy around their object of interest, often as participants in a social network. Fans typically want to know everything about a certain celebrity, following not only their professional life, but also finding out about and discussing their personal life, collecting memorabilia, merchandise and so on. Digital spaces in general offer opportunities to users who can channel their political and fan identity in a unique and creative way. This is because, of all social media, Twitter seems to be the ideal place where fans can best "follow" celebrities' thoughts and ideas. As noted in Wu's (2016: 306) discussion of Twitter, the system of "followers" in which anyone can "follow" anyone else and subsequently automatically receive others' tweets and posts, "quickly became a new measure of fame." It seems that the Twitter platform allows each user to become a potential celebrity.

It has been claimed that the human brain cannot recognise the difference between real and fictional relationships (Alderson-Dayaet et al. 2017: 106). Given that for many people politicians seem far less appealing than fictional characters, it is of little wonder that citizens become emotionally engaged in fictional representations (of others and themselves) in the media. While not eschewing politics, many users may well give current affairs less thought than, e.g. a football team or a TV series. A condition of fandom is that people may become passionately involved with celebrities they have never met. Online communities chaotically assemble to create movements where "fan-citizens [...] can perform their identities and their 'affective intelligence' via social media in ways that have left the old(er) guard uncertain whether to interpret all this as ironic, earnest, or semi-ironic" (Hills 2015: 89). With regard to politics specifically, Godin (2015: 61) claims that fan-users and their communities are constantly assigning the notion of weirdness to political parties by shaping political processes 
with strange humour, bizarre memes and use of obscure cultural items. An example of this is an internet meme that portrays Donald Trump, dressed in shining armour, in the persona of God Emperor and the ruler of Terra (Adams 2017: 2; Law 2019). ${ }^{1}$ According to Tufekci (2017: 45), this kind of phenomenon is "like slowly bubbling lava, rising higher and higher through the mantle of a volcano, but invisible." We show that a large component of this weird lava produced by fans online discussing social and political issues is humorous matter and have labelled this process weirdisation.

Celebrities play a vital role, in contemporary societies, and the link between fandoms and politics is strong. Well-known celebrity personalities often publicly display their political allegiances to parties and ideologies. Not only do celebrities become politicians but also politicians become celebrities. Barack Obama's political campaign became a clear sign of this trend where "in the media spectacle of this election Oprah cried, Beyoncé sang and crowds of young, adoring fans rejoiced" (Nagle 2017: 1). In a very conscious dis-identification, famous singers and groups have distanced themselves from politicians who use their music. Neil Young dissociated himself from President Trump's use of "Rockin' in the Free World" as background music on his political campaign, a dis-identification with Trump followed by the group REM, singer Adele and others (Ivie and Lockett, 2018). This kind of phenomenon highlights the important role played by celebrities in politics. It might be expected that once celebrity personalities become political, their fans may well follow suit, thus making a fandom a politicised space. At the 2020 USA Democratic national convention, when pop star Billie Eilish spoke out against Donald Trump ("Billie Eilish...", 2020), it is unlikely that her plea to vote for Sanders went unnoticed by her huge fanbase.

It is well documented that politics and humour have always had a close relationship especially in the form of jokes, satire and parody (Davies 2007: 301, 2011: 263) and social media has certainly amplified this phenomenon, allowing everyone and anyone to have their say both humorously and seriously. Celebrity personalities are no different and some engage in political discourse on social media, openly expressing their opinions on numerous issues. For example, when in August 2019, Prime Minister Boris Johnson moved to prorogue Parliament until October 14 before the October 31 deadline to block a no-deal Brexit, actor Hugh Grant tweeted in protest, describing Johnson, among other things, as an "over-promoted rubber bath toy." 2 Bearing in mind that humour is not necessarily always positive, Grant's tweet was indeed insulting, even though he adopted ridicule, a negative form of humour, but still a form of humour. While the remark itself caused a (brief) media storm (O'Connor, 2020), it generated numerous humorous remarks and images in the days that followed that were 'liked' (or disliked) and shared across digital spaces, amplifying and proliferating the comment exponentially. In fact, Bartlett (2017: 170-171) explains how the simplicity of digital spaces "rewards pithiness" and notes how word-count limits and dichotomies such as "Like" versus "Don't Like" are such that slogans and memes become its "currency." This kind of digital compression is undoubtedly attractive because it is quick and easy to read, appealing to the public.

As Shifman (2014: 149) notes,

whereas in the predigital era political memes were mostly part of the private lives of ordinary people who were ranting against those in power, in the digital era these expressions have become part of the public sphere: a performative display of opinions that is meant to be heard far and wide.

1 For explicit details of this phenomenon, see "God Emperor Trump" available at https://knowyourmeme.com/memes/god-emperor-trump

${ }^{2}$ The entire tweet is available at:

https://twitter.com/HackedOffHugh/status/1166740030947287040?ref_src=twsrc\%5Etfw\%7Ctwcamp\%5Etweete mbed\%7Ctwterm\%5E1166740030947287040\&ref_url=https\%3A\%2F\%2Fmashable.com\%2Farticle\%2Fhughgrant-boris-johnson-brexit-tweet $\% 2 \mathrm{~F}$ 
Tweets, GIFs and memes become part of a collective performance that creates ripples on the surface of the digital spaces. On social media, the result becomes a hive-like complex of tribal units online. Because it is fast, easy and snappy to share ideologies online, it has become a natural reflex for people to share opinions with their Facebook friends and Twitter followers in various groups to which they belong. When a celebrity shares a point of view on a social issue, fans and followers are free to engage with them by agreeing or disagreeing and, of course, by having their own say too.

Many users post opinions online on a wide array of issues, using not only irony, but also weirdness. Unlike the nonsensical, the concept of weirdness does not stop short at incongruity or even nonsensical silliness but embraces all that is different from a given norm. In response to a politician's remark on a controversial issue, Twitter users might post GIFs depicting the facial expressions of characters from films or TV series. By clicking on these GIFs, the expression (surprised, angry, amused, etc.) will go into a mode of continuous repetition. However, users who are familiar with an often-obscure pop cultural reference displayed in the gif, will recognise the character, but to many others it will remain incomprehensible, yet in either case the GIF will often be recognisable as humorous in intent. Leaving aside the inherent absurdity of the neverending repetition of a single movement or expression, GIFs aim at producing an affective response (Miltner \& Highfield 2017). Using examples that are viral at the time of writing, we wonder why the face of Tyrion raising his eyebrows repeatedly or Cersei raising a glass should be funny, and a GIF of Daenerys repeating Dracarys (literally Valyrian for "burn everything to the ground") is even more bizarre (all characters from the Game of Thrones TV saga). ${ }^{3}$ Yet these GIFs, and thousands of other similar examples, appear to be a cue for laughter, while this sharing of weird morsels of culture may well depend on the "comic disposition" (Holm 2017) of other users. Perhaps some users will find these GIFs funny because they trigger some kind of fuzzy bonding experience with others. For others, maybe the GIFs are just inappropriate and absurd, probably because of the insane repetition. GIFs appear to be a comic strategy of their own. Just as the mere sight or mention of Tony Hancock or Sidney James might trigger laughter in baby boomers brought up in the UK, inane GIFs of fictional characters appear to be an indicator of a similar confirmation of affiliation for millennials. We laugh mostly in company of others. Laughing with others is reassuring and makes us feel that we are part of a group of people with whom we have something in common. We can include or exclude others through our humorous behaviour, but above all laughter can strengthen our sense of comity. Presumably, responding to a celebrity tweet with a GIF that only other fans of that same celebrity will understand and will laugh at, will create some kind of special bond. After all, who would not be partial to the exclusiveness of an in-group of friends, especially if one of these "friends" is a celebrity?

\section{Methods and tools}

The dataset adopted in this study consists of a catalogue of Tweets produced by celebrities and their fans throughout March 2019. We selected Twitter as the social media platform to explore for three reasons. First, in the English-speaking sphere, "Twitter has emerged as a key platform on which anyone with a smartphone can engage in political discourse" (Nguyen, 2017). Second, Twitter's format is user-friendly and, third, the dynamics of aggregation of users on Twitter provides the ideal conditions for our research. However, Twitter is a chaotic environment and we did not want to follow users randomly as this would run significant risks for the overall research process, so instead, we focused our efforts on celebrities themselves, namely those that Pentland (2015: 37) has labelled "sociometric stars." These stars are people who have achieved

\footnotetext{
${ }^{3}$ Numerous Game of Thrones GIFs are available at: https://giphy.com/explore/game-of-thrones.
} 
fame, usually in the media but not only, and their lives are of great interest to many members of the public. We selected the accounts of a number of popular celebrities in a "quick and dirty" way by adopting a list of personalities found in an article that appeared in Time magazine (Samuelson 2017). According to this article, the 14 "favourite British celebrities" were Ian McKellen, Hugh Grant, Harry Styles, Lily Allen, Danny DeVito, Lena Dunham, Rob Delaney, Rag ' $n$ ' Bone Man, Jim Davidson, Russell Brand, M.I.A., Riz Ahmed, John Cleese and J. K. Rowling. The article was about how each of these celebrities would be voting in the upcoming General Election and most of them claimed to be Labour Party, Liberal Democrat supporters and Corbynites. Three of these celebrities are US citizens who have a marked interest in UK politics. Rob Delaney lives in the UK. Lena Dunham publicly endorsed Corbyn in June 2017 (Ruby, 2017). Their political engagement made this list adequately reliable for our purpose.

Using Python 2.72 software and a third-party package, we extracted all the tweets that these celebrities posted from March 1st to 28th 2019, bearing in mind that the UK was supposed to leave the EU on March 29th. Two of the 14 celebrities quoted in the Time article (Hugh Grant and Rag ' $n$ ' Bone Man) were no longer active on Twitter or had cancelled their accounts, so we could not include them in our study, leaving us with a database of 12 celebrities whose professional details, number of followers and political affiliations we have listed in Table 1.

In April 2019, we downloaded the 1,038 tweets that the selected celebrities had posted during the previous month and divided them into two categories according to whether they concerned

a) the celebrities themselves and their personal activities or

b) political, economic/ and/or social aspects of society.

For each celebrity, we selected the five tweets that received most "likes" for each of the two categories thus reducing the number of tweets to 69 , bearing in mind that the celebrities were not consistently active on Twitter, resulting in uneven postings from person to person. So, while, for example, Danny De Vito and J. K. Rowling published eight tweets between them, Russell Brand alone tweeted 92 times.

\subsection{Celebrity tweets}

We further divided the two categories of tweets according to whether or not they were in any way humorous. Deciding what was and what was not humorous was not the straightforward task we had imagined it would be. While it was easy to identify instances of traditional wordplay (e.g., puns, alliteration, chiasmus), irony, which is by its very nature ambiguous, was not always easily detectable as such. Furthermore, celebrities might couch a serious point in a light-hearted tone and follow it, for example, by triple exclamation marks and/or an emoji. This created a challenge because, while not being completely humorous per se, parts of the tweet or even single elements within a tweet did indeed signal non-seriousness. Furthermore, neither of the authors was a fan/follower of any of the celebrities and therefore frequently had difficulty in deciphering forms of in-group humour. Bearing all these issues in mind, our final working groupings for celebrity tweets were:

a) 19 serious personal tweets;

b) 11 humorous personal tweets;

c) 27 serious political tweets and

d) 12 humorous political tweets. 
From this first count, it emerged that during this period the celebrities tweeted more about political issues than their personal lives. It also emerged that serious content outstripped humorous content. Our research question was whether fans' responses would mirror their idols' stance. Above all, would they mirror their idols' political stance - in other words, would they match a humorous tweet by a celebrity on a serious ideological issue with a humorous tweet?

Table 1. Celebrities examined

\begin{tabular}{|c|c|c|c|c|}
\hline Celebrity & Activity & $\begin{array}{c}\text { Personal facts \& Political } \\
\text { affiliation }\end{array}$ & $\begin{array}{l}\text { Number of } \\
\text { Followers }\end{array}$ & $\begin{array}{c}\text { Number of } \\
\text { Tweets } \\
\text { Examined }\end{array}$ \\
\hline $\begin{array}{c}\text { Ian } \\
\text { McKellen }\end{array}$ & Actor & $\begin{array}{c}\text { Portrayed Gandalf in The Lord of } \\
\text { the Rings film saga; Cultural \& } \\
\text { LGBTQ+ icon; Popular } \\
\text { Progressive. }\end{array}$ & 4.01 million & 5 \\
\hline Harry Styles & $\begin{array}{l}\text { Singer, songwriter } \\
\text { and actor }\end{array}$ & $\begin{array}{l}\text { Philanthropist \& activist; Sex } \\
\text { icon; Popular Progressive. }\end{array}$ & 33.3 million & 1 \\
\hline Lily Allen & Singer and songwriter & $\begin{array}{l}\text { Controversial; Pop star; Labour } \\
\text { Party supporter. }\end{array}$ & 5.54 million & 7 \\
\hline $\begin{array}{l}\text { Danny } \\
\text { DeVito }\end{array}$ & Actor and producer & $\begin{array}{l}\text { Global film star: suffers from } \\
\text { multiple epiphyseal dysplasia; } \\
\text { Social Democrat. }\end{array}$ & 4.01 million & 5 \\
\hline $\begin{array}{c}\text { Lena } \\
\text { Dunham }\end{array}$ & $\begin{array}{l}\text { Actor, writer, director } \\
\text { and producer }\end{array}$ & $\begin{array}{c}\text { Star of Girls sitcom; suffers from } \\
\text { OCD \& endometriosis; Militant } \\
\text { ultra-progressive. }\end{array}$ & 5.6 million & 9 \\
\hline Rob Delaney & $\begin{array}{c}\text { Comedian, actor and } \\
\text { writer }\end{array}$ & $\begin{array}{l}\text { Co-star and co-writer of the TV } \\
\text { show Catastrophe; Influencer; } \\
\text { Left wing progressive. }\end{array}$ & 1.56 million & 10 \\
\hline $\begin{array}{c}\text { Jim } \\
\text { Davidson }\end{array}$ & Comedian & $\begin{array}{l}\text { Stand up; uses "Punch-down" } \\
\text { humour with Right Wing } \\
\text { sympathies. }\end{array}$ & 163,000 & 6 \\
\hline $\begin{array}{c}\text { Russell } \\
\text { Brand }\end{array}$ & $\begin{array}{l}\text { Comedian, actor, } \\
\text { radio host, author and } \\
\text { activist }\end{array}$ & $\begin{array}{l}\text { Outrageous \& reformed drug } \\
\text { addict; Vegetarian; from Ultra- } \\
\text { leftist to Spiritualist. }\end{array}$ & 11.7 million & 7 \\
\hline M.I.A. & $\begin{array}{c}\text { Rapper, singer, } \\
\text { songwriter, record } \\
\text { producer and activist }\end{array}$ & $\begin{array}{l}\text { Creative mixing of multiple styles } \\
\text { of music; Among Time's } 100 \\
\text { most influential people in } 2009 ; \\
\text { Ultra-progressive militant, } \\
\text { philanthropist. }\end{array}$ & 659,000 & 5 \\
\hline Riz Ahmed & Actor and rapper & $\begin{array}{l}\text { Successful migrant; Progressive } \\
\text { \& Pro-refugee activist. }\end{array}$ & 195,000 & 2 \\
\hline John Cleese & $\begin{array}{l}\text { Actor, voice actor, } \\
\text { comedian, } \\
\text { screenwriter and } \\
\text { producer }\end{array}$ & $\begin{array}{l}\text { Monty Python founder; Starred in } \\
\text { movies such as A Fish Called } \\
\text { Wanda; Liberal Democrat; Initial } \\
\quad \text { support for Brexit. }\end{array}$ & 5.56 million & 10 \\
\hline $\begin{array}{c}\text { J.K. } \\
\text { Rowling }\end{array}$ & $\begin{array}{l}\text { Novelist, } \\
\text { philanthropist, film } \\
\text { and television } \\
\text { producer, } \\
\text { screenwriter. }\end{array}$ & $\begin{array}{l}\text { Author of Harry Potter books; } \\
\text { rags to riches story; Active } \\
\text { Labour Party supporter. }\end{array}$ & 14.7 million & 2 \\
\hline
\end{tabular}




\subsection{Fan tweets}

Condensing our data was a necessary step in order to make our list of tweets manageable for a qualitative analysis so, to produce our final database, we took only the first five responses to each of the 69 celebrity tweets into account. We next classified the threads following each celebrity tweet according to whether they were a) mostly serious or b) mostly humorous. Fan responses were not exclusively verbal but often contained, or even entirely consisted of, multimodal elements, e.g., GIFs, images or video clips. Where there was visual support, it was consistently humorous, with the exception of an image of New Zealand Prime Minister Jacinta Ardern condemning those responsible for the Christchurch bombings of March 15, 2019 posted by a fan of Russell Brand following the star's tweet in which he appeals for peace and unity. All other visuals posted by fans were consistently clearly humorous to us.

\section{Content analysis}

Twitter is a chaotic environment and the threads in our database reflect the disarray of the milieu in which they occur. Furthermore, tweets were frequently impenetrable to the authors who were outsiders to the fandoms under scrutiny. Fan users would engage in repertoire that they alone could understand as might occur with any real life closed group of interlocutors and, especially with regard to humorous content, not being acquainted with the intricacies of so many different fandoms and therefore with their specific language, simple observation was not always sufficient to decipher meaning. Given that one of the many social functions of humour is to create harmony among people who share common ground, analysing some of the tweets in our dataset made us, presumably like many other users outside each specific fandom, feel alien through our lack of essential information.

Simple puns and obvious jokes were rare, but flickers of humour, that we have labelled shards proliferated in most threads. These shards of humour may consist of an emoji such as a smiley face or a gif, but above all, they included tiny instances of verbal play that would be considered out of place in serious discourse owing to their jocular tenor. Internet acronyms, flippant use of taboo terms and any hints at non-seriousness, no matter how small, we considered shards. In fact, finally, we often resorted to using what Chafe (2007: 1) labelled "the feeling of nonseriousness" and "of not being earnest" to mark a tweet as humorous.

Russell Brand posts a clear example of a humorous tweet with a photo of a cake he made and decorated claiming he is the "M'bappé of baking. Alexander the Bake." Brand playfully compares his baking skills to the footballing skills of Kylian M'bappé, considered one of the world's top footballers. He also flippantly names himself Alexander the Bake playing on the name of King Alexander III of Macedon. A fan responds to this by calling him "Eton Messi:" jokingly referring to the English dessert and the Argentinian football player. This repertoire is clearly humorous in intent. On the other hand, when Lily Allen gives up smoking and posts "I'm replacing cigarettes with apples," a fan responds with a tweet saying "20 granny Smith's a day" followed by a face blowing kiss emoji. We claim that this tweet contains a shard of humour. It superimposes the "twenty a day" reference to a packet of cigarettes onto the proverb "an apple a day [keeps the doctor away]" reinforced by the presence of an emoji.

From a content analysis of the threads, each of which was composed of the first 5 fan tweets that were triggered by one of the 69 celebrity tweets, a number of patterns emerged that we placed on a cline that went from seriousness to non-seriousness. After providing examples of serious threads, we present threads displaying non-serious flare-ups, others containing asymmetrical exchanges where serious and humorous mingle and/or clash and finally those comprising shards. Within these four macro-categories, we identify a number of trends that 
include in-group support, humorous support, guerrilla fan activity, fan worship and instances of judgement, all of which often contain shards of humour (Table 2).

\subsection{Serious tweeting}

Within our dataset, the celebrities under scrutiny posted 48 tweets that we labelled "serious" as they contained neither any hint of humour nor any suggestion of humorous intent. Personal tweets in this category included a discussion on endometriosis triggered by Lena Denham, and a number of tweets by Rob Delaney regarding the death of his young son. Threads following these tweets mirrored the serious tone of the celebrities' initial tweets. In these cases, there was no inkling of irony and no presence of a jocular tone within individual tweets. This tone of sobriety was maintained throughout the thread. Fans did not post GIFs and their use of emojis was limited to sad faces and hearts. In these threads, fans displayed empathy with their celebrities' pain.

With regard to political matters, when celebrities posted serious tweets, a similar mirroring of tone tended to emerge. This was especially the case with tweets by Riz Ahmed and Russell Brand posted following the Christchurch bombings (March 15, 2019). Fans seemed inclined to approach these tweets, and therefore the celebrities, with reverence, as though they were totems around which they had to exhibit cohesion through super-seriousness, each user trying to outdo the other with displays of support, display of common values and hero-worshipping the celebrities, e.g. "You're a breath of fresh air;" "Notice me please you're my god." Following Riz Ahmed's appeal for solidarity with Christchurch (Figure 1) his fans followed with serious tweets displaying support:
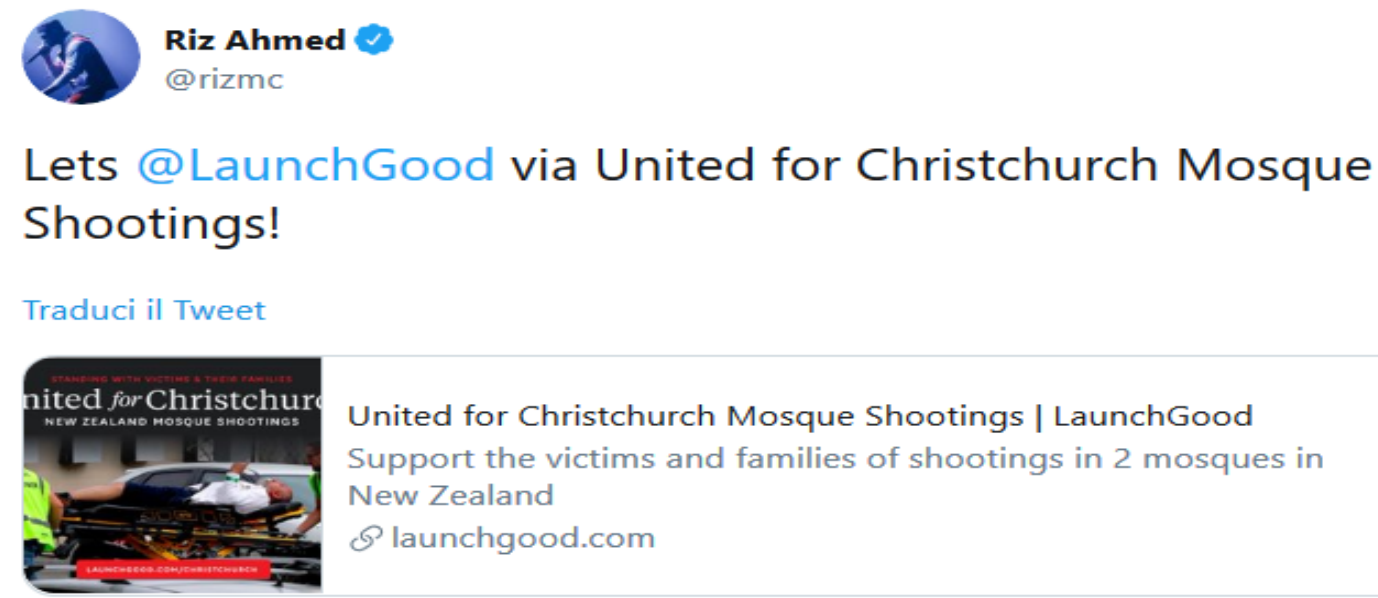

United for Christchurch Mosque Shootings | LaunchGood

Support the victims and families of shootings in 2 mosques in

New Zealand

Slaunchgood.com

FAN TWEET 1: This is a Catastrophe, Brother, 50 people murdered in cold blood in a place of worship. Women \& Children, their lives taken in seconds. Why \& how did this happen? I was in tears, when i saw this!

FAN TWEET 2: It is wonderful to see how everyone is affected by this horrible attack and participate!

Figure 1. Riz Ahmed, serious political tweet and fans' responses

Fan 2's tweet shows that s/he is so involved in the process of evoking cohesion within the group that $\mathrm{s} /$ he chooses the term wonderful in connection to the episode suggesting that the attack had 
generated the adhesion/cohesion to/of a political community that could participate by commenting and sharing their views via Ahmed's Twitter handle.

Mirroring of the serious tone was not always as clear-cut in our data. Harry Styles' tweet wishing women a Happy International Women's Day also provides an example of serious solidarity in response to a celebrity's tweet (Figure 2). The pop star, who expresses his wish (intended to be taken at face value, it would seem), i.e., encouraging women to enjoy March $8^{\text {th }}$, presumably was not aware of or did not stop to consider the feminist debate surrounding celebrating women specifically only on a particular day. Styles' tweet is taken seriously and objected to by a member of his feminist fan base causing slight aggression between other fans in their responses. Styles has unwittingly engaged in an ideological issue. What we have labelled a trial-by-Twitter is immediately triggered by Fan 1 who points out that International Women's Day is not an occasion to celebrate after which 3 fan-users jump to their idol's defence. Typical of online communication is how the non-physical presence of interlocutors may lead to misunderstanding. Clearly Styles was not aware of the political debate around International Women's Day, but when his fans attack and/or defend him, they do so by simply analysing the words at their disposal. In this case a bitter trial occurs around Styles' use of the adjective happy, in which users are split between benign and harsh condemnation for what some fans see as a gross oversight.

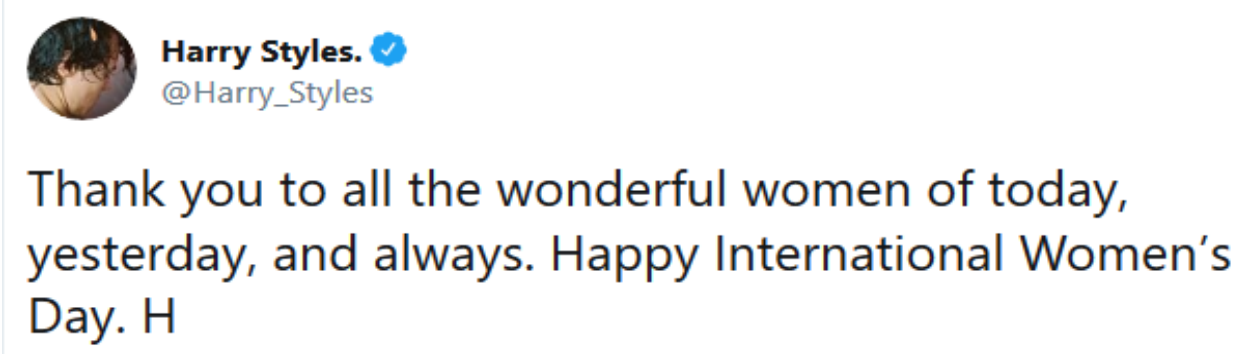

FAN TWEET 1: my angel, I know you had the best intention with this tweet but it's wrong because today it's not a day to celebrate, it's a day to fight for our rights and freedom from the patriarchy

FAN TWEET 2: he is celebrating those who have fought in the past for the rights we do have today

FAN TWEET 3: its okay but: still not a happy day

FAN TWEET 4: he didn't say it was a happy day

FAN TWEET 5: he literally wished us a happy women's day

Figure 2. Harry Styles, serious political tweet and fans' responses

The trial-by-Twitter pattern will be developed and analysed further in the following sections, but this example shows that often even innocent mistakes, remarks made in good faith, are a good enough reason in this case, very seriously, to condemn a celebrity for not being worthy of the ideal that fan users have of him.

\subsection{Non-serious flare-ups}

Along with the tweets that are clearly serious, we found tweets in which the celebrities are not serious. In effect, very few of the celebrity tweets selected (21) were indisputably humorous in intent as many included irony and were thus rather ambiguous to the reader, or else they were 
simply light-hearted. Specific cultural and political matrices adopted by fan users can be seen in sequences of user interaction, as follows.

Whereas Harry Styles (Figure 2) unthinkingly wished his fans a Happy International Women's Day in true earnest, rapper and activist M.I.A. does so, too, only she decides to do so ironically (Figure 3).

\section{Can we have \#InternationalWomensDay for 182.5 days a year? \#Equality}

\section{FAN TWEET 1: Dona da música ativista ${ }^{4}$ please come to brazil \\ FAN TWEET 2: The whole 365 would be better, tbh. \\ FAN TWEET 3: But not equal :P}

FAN TWEET 4: Oh sure, let's respect women for only half the year and go back to treating them the way we normally do the other half.

FAN TWEET 5: Treat everyone equal every day sounds like the best scenario

Figure 3. M.I.A., humorous political tweet and fans' responses

This thread provides an example of another pattern we encountered in our data, that we have named Fan Guerrilla Tactics. The celebrity's tweet provides fan users with an opportunity to decide upon a common narrative, created during a heated digital discussion, within a frame that venerates the perceived position of the celebrity on this matter.

Leaving aside Fan 1, who ignores the content of M.I.A.'s tweet but simply professes adoration, following the rapper's initial tweet, is a thread of fan responses that are in line with the celebrity's ironic tone. However, the responses present a sort of rollercoaster effect through the juxtaposition of ironic responses with serious ones. Fan 2 appears to miss M.I.A.'s irony, answering at face value that 365 days would be preferable to a mere 182.5, which Fan 3 rebuts ironically - she presumably meant to add a hyphen to produce a funny sideways "keyboard face" (:-P). Nevertheless, she notices and plays with the idea of women's days being equally valid to those of men. Fan 4, having misconstrued M.I.A.'s ironic intent, produces a sarcastic riposte and Fan 5 diplomatically closes the spat. Political arguments that overlap with celebrity content appear to fuel disagreements in which irony in particular becomes a way for disagreeing fans to reconcile and restore personal and political loyalties within the fandom.

In our dataset, President Donald Trump emerges as a comic trope in which just the mention of his name triggers humorous tweets. In fact, our dataset contains five long tweets by John Cleese which are best defined as humorous rants against the $45^{\text {th }}$ POTUS. Figure 4 illustrates one of these colourful rants as an example of what Krefting (2014: 2) defines "charged humour" that challenges "social inequality and cultural exclusion." In this particular rant, Cleese describes Trump's disordered rhetoric by punching down and comparing him to a "drunk in a coal cellar."

\footnotetext{
4 Translation: "A woman who does activist music."
} 


\title{
Recently, watching President Trump, I had an insight.
}

\author{
He always rambles, of course, lurching from one subject \\ to another like a drunk in a coal cellar. When he starts a \\ sentence, he has no idea where he will finish up, or what \\ point or resentment will hop into his mind next
}

\begin{abstract}
FAN TWEET 1: GIF (Major Gowen)
FAN TWEET 2: In other words, coked the fuck out

FAN TWEET 3: More like strung out on Adderal \& other "metabolic boosters" prescribed to him. Which he takes according to Dr.'s orders, which is why President Sundown flags later in the day.

FAN TWEET 4: oh I don't suspect he is a cokester, currently...but i do believe he has retained some of the characteristics of yrs of abuse.... and currently taking adderal like many former speed freaks, as you suggest

FAN TWEET 5: Mebbe, but he's known to not drink at all. Then again, so much of his image is a lie, \& if anyone is stupid enough to think cocaine won't leave behind marks on the brain it's Putin's buttplug.
\end{abstract}

Figure 4. John Cleese, humorous political tweet and fans' responses

The thread following the tweet illustrates how the humour triggered by the celebrity reverberates in his fans' responses. The thread opens with a GIF featuring the Major, a permanent resident in the fictional Fawlty Towers Hotel run by Basil Fawlty in the eponymous sitcom of the late 1970s. Fans will recognise the Major as an old, confused, retired and slightly alcoholic military officer who might well be compared to Trump. In the four tweets that follow, fans discuss the likelihood of Trump's addiction to cocaine and/or amphetamines. Now, while this may appear to resemble a serious discussion, it is far from it, as we see from the use of taboo words, fucked the coke out, and slang, e.g., cokester and speed freak. Responses are couched in humorous terms, but at the same time, they are highly charged and critical of Trump who they name President Sundown, presumably because of his night time activity on Twitter, and describe him as Putin's buttplug. This discussion about Trump magnifies his weaknesses, invents a few causes, and creates a "celebrity-politician" bashing process framed by using humour, insult and creative embellishment. In fact, online there seems to be no middle ground for the celebrity Tweeter (and POTUS), Trump who is the subject of either bashing or veneration. Anthropologists have traced the kind of group ridicule that is so pervasive on social media, back to hunter-gatherer communities (Boehm 1993: 230; Lomas 2009: 46). With regard to ridicule, Trump online embodies an individual who is targeted and degraded through humour by the "digital collective intelligence of a like-minded group of people" (Pentland 2014: 33-34).

This thread, too, displays a trial by Twitter in which Trump stands accused. In this particular case, the trial contains no defence but only prosecution, whereas in other Twitter trials, we may find the presence of resistance, as in the case of a thread by followers of Shakespearean and film actor Ian McKellen. In early March 2019, McKellen produced a podcast that included some 
controversial comments about Bryan Singer and Kevin Spacey, two men who had been accused of sexual misconduct. He subsequently apologised for his comments yet continued to be arraigned by his followers. This thread illustrates how, despite a lengthy and serious apology by the actor that continued over four tweets, fan-users continued to prosecute him, yet by using humour abundantly (Figure 5).

Ian McKellen

@lanMcKellen

2/4 My intention was to encourage the LGBT audience I

was addressing, to be proud and open about their

sexuality. In doing so, my point was clumsily expressed. I

would never, ever trivialise or condone abuse of any

kind.

FAN TWEET 1: Ian McKellen just wanted to harmlessly encourage "pedosexuals" like Kevin Spacey and Bryan Singer to be proud and open about their sexuality. WOW.

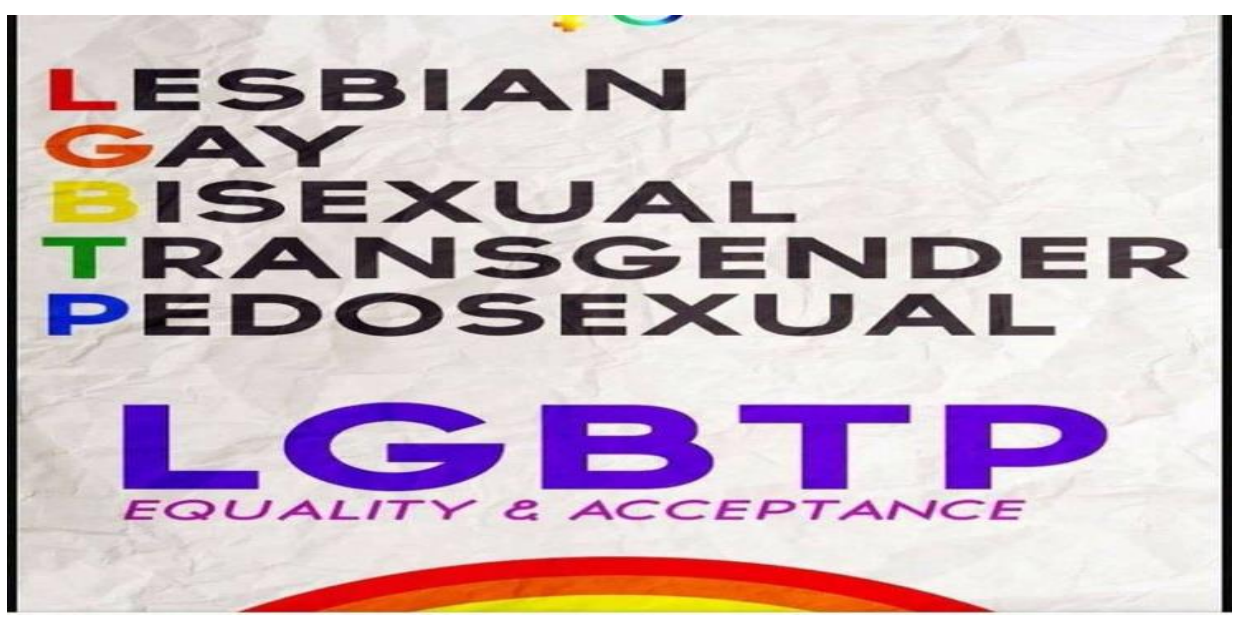

FAN TWEET 2: GIF (Family Guy) ${ }^{5}$

\section{FAN TWEET 3:}

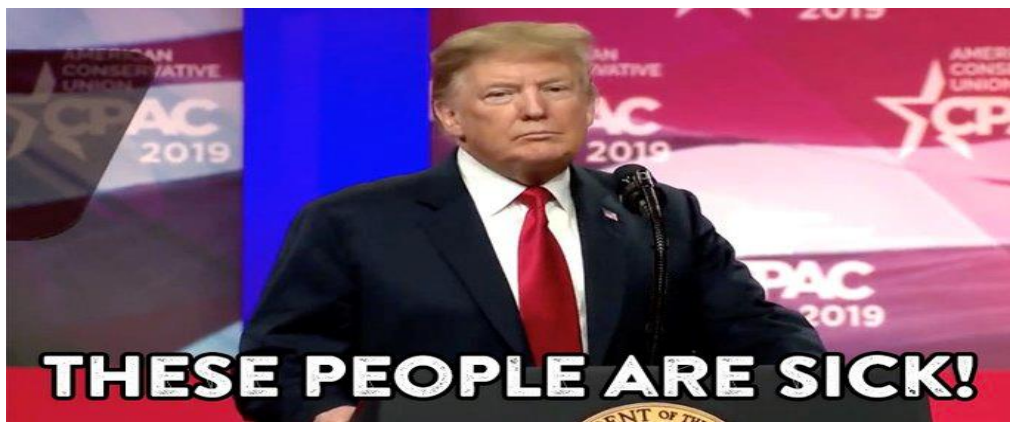

FAN TWEET 4: Forgetting that Trump told an 11 year old that he'd end up dating her.

Figure 5. Ian McKellan, serious political tweet and fans' responses

\footnotetext{
${ }^{5}$ Available on Twitter at: https://twitter.com/painefultruths/status/1102134485372551174
} 
McKellen's trial by Twitter contains charged humour. The first tweet in response is purely ironic and contains a parodic image of an LGBT rainbow banner with the addition of the letter P standing for "Pedosexual." The second fan simply posts a short video from the series Family Guy -"Help I've escaped from Kevin Spacey's basement" - and the third, a meme of Trump declaring, "These people are sick!" The last tweet refers to a video of Trump in which he tells an 11-year-old girl that he would be dating her in ten years' time. All the prosecuting evidence in the trial is humour-based but is neither gentle nor fond. This is an example of a serious tweet by a celebrity that is followed by a series of humorous tweets in which he is condemned for the "crime" for which he has however apologised. It is worth highlighting that the "crime" was verbal, supporting the disgraced perpetrators. Clearly, these fans adhere to a different ideological alliance from that attributed to McKellen. The invasion of digital spaces by antagonistic users who frame their opinions humorously, is a reversal of the celebrity bashing process, introduced above in the Cleese/Trump example (Figure 4). Here we find users posting several comments that are enhanced by irony and visual elements that downgrade the celebrity. The third tweet in this thread, however, is an image of Trump declaring "these people are sick." This is a complete change to what has gone before, a clarion cry from elsewhere. Using an image like this can be compared to the way in which, in Golding's Lord of the Flies, the head of a pig on a stick signals to all other users that another tribe is occupying this space now. Like the boys on the island in the novel, in digital spaces users create symbolic borders using memes, in-group gifs, and forms of caustic humour. Fans are engaging in what Bartlett (2015: 30) labels "crapflooding," a multimodal form of trolling that occurs through nonsensical, absurd, and often repetitive postings.

\subsection{Asymmetrical exchanges}

Asymmetrical exchanges refer to Twitter threads where serious and humorous content mingle, like, for example, the humorous reaction of fans to a serious tweet posted by a celebrity. In such exchanges, users seem to shift the conversation in a direction that is more to their liking by juxtaposing serious and humorous tweets.

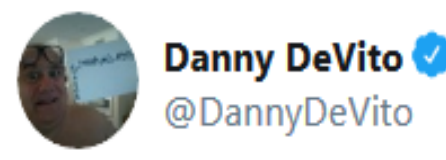

\section{Wheeler Must Act Against Climate Change Now}

FAN TWEET 1: (Videoclip from It's Always Sunny in Philadelphia). ${ }^{6}$

FAN TWEET 2: Never thought I'd say this but they're currently more pressing issues than rum ham

FAN TWEET 3: (Nonsensical GIF)

FAN TWEET 4: Notice me please you're my god

FAN TWEET 5: The lack of Ozone is burning me head...

Figure 6. Danny De Vito, serious political tweet and fans' responses

\footnotetext{
${ }^{6}$ Videoclip from It's Always Sunny in Philadelphia - Rum Ham Returns! Available at: https://www.youtube.com/watch?v=VVHm6k4wed8
} 
The thread following Danny De Vito's clearly serious tweet in which he makes a plea regarding the issue of climate change, shows various fans employing weirdisation (Figure 6). There is no ambiguity in the tweet - it cannot be mistaken for irony - yet his fans respond nonsensically. The thread opens with a video clip of scene from the sitcom It's Always Sunny in Philadelphia, in which De Vito enters a room holding a Rum Ham. There is absolutely no connection between climate change and rum ham or the nonsensical clip (presumably a significant morsel of pop culture to De Vito's particular fandom). While Fan 2 gently challenges Fan 1 for making light of a serious issue, he is ignored by others - one fan posts an absurd GIF while another simply adulates De Vito with "Notice me please you're my god" and another makes a silly remark about ozone.

If De Vito's fans eschew his serious plea with humour, Jim Davidson's fans do the opposite in answer to the casual tone of a political tweet expressed in a humorous style (Figure 7). Davidson's tweet contains a shard, blocking lefties, but his fans reply blithely ignoring the political content of their idol's tweet, and veering the conversation towards football (Fan Tweets 1-4) and personal matters (Tweet 5). In-group ridicule of Jim Davidson's team kicks off the conversation (Tweet 1). Essentially followers change the subject and steer the thread away from politics and towards football that is more relevant to their bonding.

The political content of this lad-made-celebrity tweet is treated superficially. Users seem to be saying "OK, so we'll all block lefties too, but let's talk about football." It appears that agreement with Davidson is tacitly given, the group is loyal, but a personal, relaxed discussion is more to their taste and refers to what they have in common and that unites them. Davidson has right-wing sympathies that his fans do not contest, yet they seem more interested in being lads together than blocking lefties. Engaging in a good-natured conversation around football, a feeling of "being lads together," provides the glue for a small circle of fan-users. There are strong synergies between online and real-life conversation (Oeldorf-Hirsch et al. 2017: 98), so it is not surprising that users often embrace the fun and jollity of their digital time beyond the political.

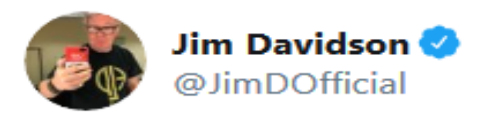

\section{Having a great afternoon blocking lefties}

FAN TWEET 1: Not come to Bristol to watch Charlton nil, Jim? Your boys have a tricky one against my mob in this swirling wind

FAN TWEET 2: That's a shame. Good pies and pasties at the Mem.

FAN TWEET 3: Just had fun watching watford win.

FAN TWEET 4: Have you heard what happened to Berni Flint? I first saw you with him at Tameside Theatre many many years ago!!

Figure 7. Jim Davidson, humorous political tweet and fans' responses

\subsection{Shards of humour}

Interpreting the degree to which a tweet is serious or humorous in intent may not always be straightforward for the analyst. One of the reasons for this difficulty in interpretation is the absence of a comic frame. Often the simple presence of a word, an idiom or a non-verbal sign jars with the rest of tweet rendering it somewhat less than serious while not necessarily making it completely humorous. Rob Delaney is a US citizen with left wing tendencies who lives in the 
UK. His tweet about the NHS is serious (Figure 8). However, there is a shard of humour in the use of the expression both sides suck. Delaney could have used a more formal expression but opted for the slang/vulgar suck inserting a bit of humour in the tweet. The thread following Delaney's tweet contains four tweets posted by medics. The tweets show support for the comedian's feelings about the NHS and are serious but, as in Delaney's tweet, contain shards. The question Can we keep you and send Rees-Mogg and Boris to Trumpland please? exemplifies what we mean by shards, Trumpland is a flippant way of naming the USA, and calling Boris Johnson by his first name alone is jokily disrespectful. Asking whether they "can send" the two conservative politicians to the USA is jestingly asserting that they and Delaney have the power to change the situation or wish they did. The overstated adoration expressed towards Delaney by the medics, (We are completely in love with you) can also be considered a humorous shard followed by the $x$ for "kisses" from Delaney himself in thanking the doctors for their tweets. The idolatry of fans in this example usually applies to the digital fandom at large.

rob delaney
@i I'm a dues payiney
one day be a citizen so I can vote for them in a GE since
they care about the NHS, social care, education \& ppl w
disabilities. I am almost physically sick watching smart
ppl say "both sides suck."

FAN TWEET 1: As a doctor in the NHS I am thankful for the health of the nation that the NHS provides. It is such a precious wonderful gift. Can we keep you and send ReesMogg and Boris to Trumpland please? We are completely in love with you

(Delaney Tweet: Thank you Dr. B xx)

FAN TWEET 2: Absolutely right. Being in the EU didn't protect us from Tory austerity. And New Labour didn't halt the slide towards privatised NHS. At last labour's showing the political will to change all that. We should fight to get Labour in and Tories out.

(Delaney Tweet: Thanks Dr. G! x)

FAN TWEET 3: Thanks for speaking out.

FAN TWEET 4: I'm an NHS health visitor. In the last 8yrs the services I can call on to support families have gone. It's draining and sad. Myself \& colleagues are constantly worried \& exhausted. Voting labour is the only way to stop this. I tell student nurses this is the only answer.

Figure 8. Rob Delaney, serious political tweet and fans' responses

In a clear instance of a celebrity framing his political stance humorously, John Cleese attacks Donald Trump (Figure 9). As is often the case on social media, mere mention of President Trump appears to be a trope that triggers humour. In one ranting tweet, Cleese refers to Trump's tweet of March $5^{\text {th }}, 2019$, in which the President compares the Democrat Party's inquiry into his alleged obstruction of justice and abuse of power as a "big, fat fishing expedition" ("Trump Blasts...", 2019). Cleese links the President's reference to fishing to the final scene of the wellknown film A Fish Call Wanda, in which Cleese, as British solicitor called Archie, is standing 
in a barrel of petrol on the runway at Heathrow airport while US trickster Otto (Kevin Kline), is pointing a gun at him. ${ }^{7}$ Cleese's followers get the filmic reference - a film that on one level is a criticism of both the UK and the USA - but, rather than contribute to the political discussion, they elaborate upon Cleese's irony in the wordplay that follows.

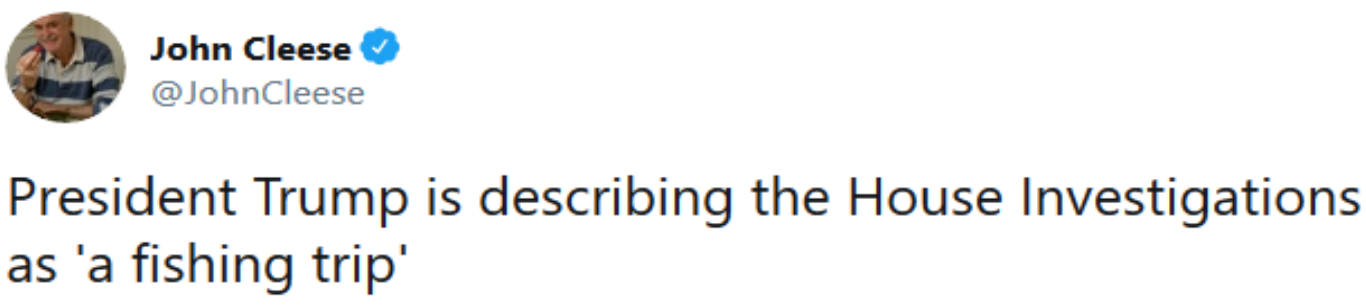

\title{
You don't have to travel when you're shooting them in a barrel
}

\author{
FAN TWEET 1: I wanda what kind of fish Trump is. \\ FAN TWEET 2: GIF \\ FAN TWEET 3: Not Nemo Wanda watch the movie again please get it right Enough \\ bullshit \\ FAN TWEET 4: That's a clownfish, but thanks for playing. \\ FAN TWEET 5: Nemo is a clownfish. That is the point mate. Wanda was Not. Watch \\ the movie and see what Wanda was.
}

Figure 9. John Cleese, humorous political tweet and fans' responses

Verbal aggression arises between fans when one of them posts a GIF portraying the cartoon fish Nemo (rather than Wanda, the fish that appears in the movie). The fan is swiftly corrected. However, although the absence of physical context in digital spaces can contribute to mistakes or aggression, as may have occurred here, the individual tweets display a degree of fan oneupmanship (all five fans are male and all are clearly lionising John Cleese). The use of FanGuerrilla-tactics is central to this thread. Aggression and mockery are interlocked to establish which of the users is the most "true fan." Presumably, fans are supposed to know every detail about their idol and confusing Wanda for a clownfish is interpreted as sacrilege or ignorance. However, of much more interest is that the fans, albeit humorously, sidestep the political content of Cleese's tweet. Cleese is criticising Trump yet his fans ignore the politics and joke about fish. Whereas previously (see Figure 4) Cleese's fans had participated in "Trump bashing," here they compete as to who knows most about a film involving the celebrity. Yet again, as noted earlier, knowing about and worshipping the details of the idol's celebrity can eclipse social and political matters for fans. This, however, was not the case in the thread following Delaney's tweet (Figure 8) possibly because the responses came from medics working in the NHS and therefore personally involved in the issue at stake.

Frequently, celebrities join the fray to condemn and comment on scandals, supported by their followers. Lena Dunham, widely known for her role in the TV series Girls, weighed in on Twitter on a college scam that dominated headlines, when the FBI discovered that "parents allegedly spent as much as millions of dollars in bribes to help admit their children into elite universities" (Nissen 2019).

${ }^{7}$ A Fish Call Wanda, 1988. Directed by John Cleese and Charles Crichton, UK. 


\section{all the people involved in this college scam should have gathered their money and started a small elite college where Lori Loughlin teaches a class on smiling}

FAN TWEET 1: Am I the only one thinking, that for half a million dollars, Lori could have bought herself a smart kid!

FAN TWEET 2: No.... It's a little more serious than that. All of those people should pay reparations to all of the Black and Brown parents getting prosecuted for using an address to send their children to a better public school. Life and death for kids like mine to get to college

FAN TWEET 3: I remember my cousins having to give their grandma's address \& they lived right across the street from me but that was the border. They did't get caught but their neighbor did, made the kid transfer in the middle of the school year to a much worse school in a bad neighbourhood

FAN TWEET 4: (Laughing smiley emoticon) -- as a lower middle class parent of kids who worked their assess off to go to college and graduate schools, this is maddening and feels like something Donald Trump would do.

FAN TWEET 5: Donald Trump didn't though. Name-caller. Stop hating.

Figure 10. Lena Dunham, humorous political tweet and fans' responses

When non-serious shards enter political argument, they may result in trial by Twitter. Lena Dunham is a politically active American actor, writer and producer. Her ironic tweet (Figure 10) mocks the actor and model Lori Loughlin who is among several celebrities involved in the scandal in which they allegedly paid to get their children into the best US colleges. In response to the first ironic tweet echoing Dunham's sarcasm that mocks Loughlin, Fan 2 responds that It's a little more serious than that - s/he actually rebukes Fan 1 for making light of a felony. In fact, subsequent tweets contain personal and detailed stories that contribute to the overall opinion that the wrongdoing celebrities deserve harsher punishments. These online shards of humour are employed not only to ridicule the "scoundrels" who committed the felony, but also to confirm cohesion with a group that behaves in what they all consider to be the "right" way. However, Fan 4 draws Trump into the argument causing Fan 5 to jump to the President's defence, interrupting the humorous flow of the brief celebrity bashing with very three short utterances. The cohesion is broken; they agree on the corruption scandal, but not on Trump. The entire tone changes when Fan 5 jumps in. Yet the telegraphic nature of Name-caller. Stop hating expresses dissent by changing the subject.

\section{Discussion}

The use of humour, especially in the form of shards that appeared regularly, frequently and in a variety of frames was pervasive in our dataset. The only places from which humour was absent 
was in tweets around the subject of death, suggesting that it may still be a societal taboo. Gallows humour is popular yet responding humorously to serious tweets involving death was clearly avoided. The most interesting finding was that, in their tweets, celebrities blended the personal with the political and fans chose to either agree, disagree or ignore their idol's political standpoint mainly through humorous tweets. Our resulting hypothesis to explain the chaotic nature of these interactions is that the moral values of both celebrities and fans are accelerated in online spaces to affect their political beliefs in everyday interactions. It is a continuous and playful sequence of moral rituals relevant for the in-group, to quote Davies (2002: 47) "those who belong to an established majority are enclosed in a bubble of their own "normality" and, therefore, see the behaviour of minorities as comic deviations" and vice versa. This phenomenon is part of an emerging trend in exploring the meeting point of humour and politics, namely LOLitics. Tay (2014: 70) sees this kind of online interaction in the following way: "LOLitics can be as much a part of the overall media ecosystem as they are digital 'inside jokes', and users truly began to harness this benefit during the 2012 Presidential election." He adds that often "all that matters are play for play's sake." Therefore, while celebrity tweets were patently clear and understandable in our collected data, fan tweets provided numerous instances of weirdness. Obscure references and cryptic humour that did not seem in any way connected to the celebrity tweet to which they were responding were frequent.

Table 2. Threads and celebrity tweets, per category. The number of threads that contain shards of humour are within brackets

\begin{tabular}{|l|c|c|c|c|}
\hline \multicolumn{1}{|c|}{ Categories } & $\begin{array}{c}\text { Political } \\
\text { Serious }\end{array}$ & $\begin{array}{c}\text { Political } \\
\text { Humorous }\end{array}$ & $\begin{array}{c}\text { Personal } \\
\text { Serious }\end{array}$ & $\begin{array}{c}\text { Personal } \\
\text { Humorous }\end{array}$ \\
\hline Total number of tweets & 27 & 12 & 19 & 11 \\
\hline In-group support & $11(4)$ & $1(1)$ & $10(3)$ & $4(1)$ \\
\hline Serious/Worship & $6(1)$ & $1(1)$ & $5(2)$ & \\
\hline Humorous support & 5 & 6 & 3 & 6 \\
\hline Guerrilla tactics/ Antagonism & $5(4)$ & $4(4)$ & 1 & $1(1)$ \\
\hline
\end{tabular}

This enigmatic interaction between users emerged especially when fan responses did not mirror the tone of the initial celebrity tweet. Users would go off on a tangent of strictly in-group innuendos and/or nonsensical gifs. The "Matthew principle" ${ }^{8}$ seems to manifest itself not only within the pool of users but also between users and non-users, through a dynamic process where the weird gets weirder while the outsiders are increasingly forced to remain on the outside of the fan-group. In order to share a fandom's beliefs and norms, users adopt different forms of weirdness. This weirdness is apparent even when followers invade the digital spaces of celebrities that hold opposing political and social values. Wordplay, innuendos, GIFs and memes accelerate a shift towards weirdness on social media as users engage with celebrities and cultural phenomena in random patterns.

In-group support and group loyalty is constructed, among other things, through a sort of contest in which the fan who posts the weirdest tweet comes out top of the thread. In the Twitterverse, "comic disposition" is important in belonging and understanding what is going on. In-group building and maintenance and a drive towards information symmetry are an essential part of humorous interaction and even if someone does not get a weird reference, if they are part of a fandom, they will be disposed to accept it as humorous. In our dataset, the techniques

\footnotetext{
${ }^{8}$ According to this principle adopted by sociologist Robert K. Merton, "the rich get richer while the poor get poorer" (1973: 56-63), in other words, advantage begets further advantage.
} 
through which weirdness was channelled were varied and our examples provide the main patterns in which it occurred.

Lurkers often pick up weirdness. In an example of the reversal of the "digital invasion" we described in the case of Ian McKellen, who was ridiculed by a right-wing user, a left-wing user, dryly corrects Jim Davidson's English for comedic effect. In response to Davidson's tweet

Inter national womens day and the David Lammy mob are too much for me. I m done. By twitter

a fan points out to the comedian that

'Inter' and 'national' is one word. Womens needs an apostrophe, as it is a day, which belongs to them. You need an apostrophe between 'I' and ' $m$ '. Assuming you intend to leave Twitter (rather than Twitter having written your Tweet), it's 'Bye' not 'By'. Otherwise, good try.

Another user who commented, "I have enjoyed these corrections far too much, Thank you!" regarded this exchange between user and celebrity as a performance. ${ }^{9}$ Therefore, weirdness seems to be passively absorbed and encouraged, with humorous delight, by an unseen, invisible mass of "lurkers" who observe and absorb thousands of tweets without engagement in the discussion.

This mingling of the political with the personal, serious with humorous, and weird with normal, results in three general patterns of user-celebrity interaction. First, the framing of a tweet by a "star performer" (Pentland 2014: 36-37), such as a celebrity, decidedly affects the resulting thread of fan users who gladly answer with humour, even if their content is not always in line with the original tweet. Second, while political, economic and social topics occur in celebrity tweets 39 times, framing notwithstanding, they trigger nine antagonistic threads, of which eight are humorous. Within the 30 personal celebrity tweets, two antagonistic threads in response both contain humour. Third, humorous shards are however present in other trends, e.g., in-group support, guerrilla tactics. According to this small study, political polarisation seems to proceed hand in hand, with humour, and often weirdness, to guide political divergence towards forming new, unexpected shores within digital spaces.

\section{Conclusion}

According to Godin (2011: 53-54), a human tendency towards tribalism, as it plays out in digital spaces, is causing spiralling in new directions. This suggests that "the weird are now more important than the many, because the weird are the many." Godin is describing a place where people are free to interact with their favourite celebrity, post funny pictures and laugh with their friends, but also where politics, celebrity culture and humour seem to mesh together to create a slack formation of users online, with content being chaotically added every day. The users who are quick to ridicule, antagonise or worship, are motivated by cultural and political ingroupishness. Yet, chaos is merely order waiting to be deciphered (Saramago 2005: 87). Most of the tweets we gathered, in which users responded to a celebrity's political thought with simple agreement or disagreement displayed the users' need to make their allegiances known, in line with Bartlett's (2017: 170-171) assertion that "with its word-count limits and networked sharing, there's no time for the boring business of negotiation and compromise online."

While at a first sight, some of the comments by fans could seem quite distant from political questions, they do however engage with several cultural themes that indirectly connect with deeper social issues. How celebrities approach topics such as violence, women's rights and even

${ }^{9}$ This single response had received one "like" by May $17^{\text {th }}, 2019$. 
colleges scams, are mirrored in real life political talking points and if fans avoid the political point made by a given celebrity, they signal that the celebrity is part of their community by showing online familiarity (see Figures 6 and 7). This seemingly random behaviour creates the feeling of community online that every user senses when they join a forum or blog and that can reinforce a political statement made by a random user that started a particular thread. As we have seen, when a celebrity engages in political argument, this often provokes the kind of heated discussions that we labelled Fan-Guerrilla tactics, where humour emerges and reshapes the conversation like the shards in a kaleidoscope.

In the digital jungle, humour may contribute to the rise and fall of politicians and celebrities. Some politicians, such as Berlusconi, Trump and Johnson, adopt humorous language presumably to enhance their popularity, which it may well do although at the same time, such behaviour may increase the public's polarisation. In this jungle, all users, groups and celebrities have a digital Red Queen problem causing them to constantly adapt, evolve and proliferate in order to survive while pitted against ever-evolving opposing organisms in a constantly changing environment (Lythgoe \& Read 1998). Given the month we examined, we had expected to find a focus on Brexit and British politics emerging from our data. While we did find some interaction on this subject, other political issues emerged more frequently, namely climate change, political correctness, paedophilia, and, in particular, Donald Trump. The constant evolution of celebrities' content, and that of their fans, is probably the reason why we found a broader spread of political topics, ranging from Trump to climate change and gender equality. Nevertheless, humour emerged as central to the development of all these conversations/interactions/digital formations.

Exploring online morality seems to be the key to unlocking the potential of this weird randomness and its consequences for political processes that are often embedded in cultural items, references and images. Future studies of online phenomena that encompass humour and politics will need to be more open-minded and careful on how the two are part of an endless whirlwind of impossibly fast online renewal as communities and their invisible values and ingroup cues emerge and then change.

The consequences of examining these processes of development and evolution are crucial in considering the role of humour and political competition in the digital as well as the real world. In digital spaces, politics seems to be constantly the focus of weirdness and humour, linked to in-group references. As digital spaces exist in a back-and-forth relationship with the material world, exploring the processes of shifting formations and reformations could offer rewards in terms of understanding contemporary political phenomena. Humour studies could equally benefit from embracing an additional viewpoint on the role of humour as digital spaces offer largely unexplored avenues of research. According to Godin, weirdness will consume us all, so why not let it do so with memes, GIFs and shards of humour?

\section{References}

Adams, S. (2017). Win Bigly Persuasion in a World Where Facts Don't Matter. New York: Penguin.

Alderson-Daya, B., Benini M. \& Fernyhough, C. (2017). 'Uncharted features and dynamics of reading: Voices, characters, and crossing of experiences'. Consciousness and Cognition 49, pp. 98-109.

Bartlett, J. (2015). The Dark Net inside the Digital Underworld. New York: Melville House.

Bartlett, J. (2017). Radicals Outsiders Changing the World. London: Heinemann.

'Billie Eilish at the DNC: 'Trump is destroying our country and everything we care about' video'. (2020). The Guardian. Retrieved 16 January 2021 from: 
https://www.theguardian.com/music/video/2020/aug/20/billie-eilish-dnc-trump-isdestroying-our-country-video

Billig, M. (2005). Laughter and Ridicule: Towards a Social Critique of Humour. London: Sage. Boehm, C. (1993). 'Egalitarian behaviour and reverse dominance hierarchy [and comments and reply]'. Current Anthropology 34 (3), pp. 227-254.

Chafe, W. (2017). The Importance of not Being Earnest. Amsterdam: John Benjamins.

Davies, C. ([2002] 2017). The Mirth of Nations. Routledge: London \& New York.

Davies, C. (1982). 'Ethnic jokes, moral values and social boundaries'. The British Journal of Sociology 33 (3), pp. 383-403.

Davies, C. (2007). The Strange Death of Moral Britain. New Brunswick: Transaction.

Davies, C. (2011). Jokes and their Targets. Bloomington: Indiana University Press.

Godin, S. (2011). We Are all Weird the Myth of Mass and the End of Compliance. The Domino Project.

Haidt, J. (2012). The Righteous Mind: Why Good People Are Divided by Politics and Religion. New York: Vintage Books.

Hills, M. (2015). 'The 'most unlikely' or 'most deserved cult': Citizen-fans and the authenticity of Milifandom', in Jackson, D. \& Thorsen, E. (eds.). Retrieved 27 May 2019 from http://www.electionanalysis.uk/uk-election-analysis-2015/section-7-popular-culture/themost-unlikely-or-most-deserved-cult-citizen-fans-and-the-authenticity-of-milifandom/

Holm, N. (2017). 'On-line deadpan and the comic disposition'. Retrieved 9 July 2019 from https://mro.massey.ac.nz/handle/10179/13374

Hwang, T. (2010). 'Digital transforms activism: The web ecology perspective', in Joyce, M. (ed.). Digital Activism Decoded The New Mechanics of Change. New York: International Debate Education Association, pp. 119-137.

Ivie, D. and Lockett, D. (2018). 'A brief history of musicians saying 'Hell no' to Donald Trump's using their songs'. Vulture. Retrieved 16 January 2021 from https://www.vulture.com/2018/11/the-history-of-musicians-rejecting-donald-trump.html

Jackson, D. and Thorsen, E. (eds.). (2015). UK Election Analysis 2015: Media, Voters and the Campaign Early Reflections from Leading UK Academics. Poole: Centre for the Study of Journalism, Culture and Community Bournemouth University.

Jacobson, B. (2003). 'The social psychology of the creation of a sports fan identity: A theoretical review of the literature, Athletic Insight'. The On-line Journal of Sports Psychology 5 (2).

Krefting, R. (2014). All Joking Aside. Baltimore: Johns Hopkins University Press.

Kristian, B. (2017). 'Meet the huge on-line forum where President Trump is "God Emperor"'. The Week. Retrieved 27 May 2019 from https://theweek.com/speedreads/687829/meethuge-on-line-forum-where-president-trump-god-emperor

Kuipers, G. (2010). 'Humor styles and symbolic boundaries'. Journal of Literary Theory 3 (2), pp. 219-239.

Law, T. (2019) 'Massive Emperor Trump float presides over Italian carnivale'. Time. Retrieved 27 August 2020 from https://time.com/5526224/trump-float-italy/

Lomas, W. (2009). 'Conflict, violence, and conflict resolution in hunting and gathering societies'. Totem: The University of Western Ontario Journal of Anthropology 17 (1), pp. 43-50.

Lythgoe, K. A. \& Read, A. F. (1998). 'Catching the Red Queen? The advice of the rose'. Trends in Ecology and Evolution 13, pp. 473-474.

Martin, R. (2007). The Psychology of Humor: An Integrative Approach. Burlington (MA): Elsevier Academic Press.

Merton, R. K. (1968). 'The Matthew Effect in science'. Science 159 (3810), pp. 56-63.

Miltner, K. M. \& Highfield, T. (2017) 'Never gonna GIF you up: Analysing the cultural significance of the animated GIF'. Social Media + Society 3 (3), pp. 1-11. 
Nagle, A. (2017). Kill All Normies: The On-line Culture Wars from Tumblr and 4chan to the Alt-right and Trump. Winchester: Zero Books.

Nguyen, M. (2017). 'Twitter's role in politics'. The Northwestern Business Review. Retrieved 27 August 2020 from https://northwesternbusinessreview.org/twitters-role-in-politicsb3ed620465c9

Nissen, D. (2019). 'James van der Beek, Lena Dunham and other stars react to college admissions scandal'. Variety. Retrieved 27 May 2019 from https://variety.com/2019/biz/news/college-admissions-scandal-lori-loughlin-felicityhuffman-celebrities-react-1203161880/

O'Connor, R. (2020). 'Hugh Grant posts furious Twitter rant over Boris Johnson's plan to suspend parliament: 'You will not $\mathrm{f}^{* * *}$ with my children's future'. The Independent. Retrieved 16 January 2021 from https://www.independent.co.uk/artsentertainment/films/news/hugh-grant-twitter-boris-johnson-parliament-suspendedprorogued-queen-latest-a9083091.html

Oeldorf-Hirsch, A, Birnholtz, J. P. \& Hancock, J. T. (2017). 'Your post is embarrassing me: Face threats, identity, and the audience on Facebook'. Computers in Human Behaviour 73, pp. 92-99.

Pentland, A. (2015). Social Physics: How Social Networks Can Make us Smarter. Penguin: New York.

Ruby, J. 2017. 'Lena Dunham endorses Jeremy Corbyn for Prime Minister as she wades into British politics'. Evening Standard. Retrieved 16 January 2021 from https://www.standard.co.uk/showbiz/celebrity-news/lena-dunham-endorses-jeremycorbyn-for-prime-minister-as-she-wades-into-british-politics-a3558231.html

Samuelson, K. 2017. 'How your favorite British celebrities are voting in the U.K.'s General Election'. The Time. Retrieved 16 January 2021 from https://time.com/4793855/britishcelebrities-general-election/

Saramago, J. (2005). The Double. Vintage Books: London.

Shifman, L \& Lemish, D. (2010). 'Between feminism and fun(ny)mism: Analysing gender in popular Internet humor'. Information, Communication and Society 13 (6), pp. 870-891.

Shifman, L. (2007). 'Humor in the age of digital reproduction: Continuity and change in Internet-based comic texts'. International Journal of Communication 1, pp. 187-209.

Shifman, L. (2014). Memes in Digital Culture. Cambridge: MIT University Press.

Storer, N. W. (1973). The Sociology of Science. Chicago: University of Chicago Press.

Tay, G. (2014). 'Binders full of LOLitics: Political humour, internet memes, and play in the 2012 US Presidential Election (and beyond)'. European Journal of Humour Research, 2 (4), pp. 46-73.

'Trump blasts House Democrats' 'fishing expedition'. (2019). BBC News. Retrieved 20 January 2021 from https://www.bbc.com/news/world-us-canada-47451601

Tufekci, Z. (2017). Twitter and Tear Gas: The Power and Fragility of Net-Worked Protest. New Haven (CT): Yale University Press.

Wu, T. (2016). The Attention Merchants the Epic Scramble to Get Inside our Heads. New York: Penguin. 